\title{
Article \\ Sarcoplasmic Reticulum from Horse Gluteal Muscle Is Poised for Enhanced Calcium Transport
}

\author{
Joseph M. Autry ${ }^{1, * \mathbb{C}}$, Bengt Svensson ${ }^{1} \mathbb{(}$, Samuel F. Carlson ${ }^{1}$, Zhenhui Chen ${ }^{2}$, Razvan L. Cornea ${ }^{1} \mathbb{D}$, \\ David D. Thomas ${ }^{1,+(D)}$ and Stephanie J. Valberg ${ }^{3, *,+}$ \\ 1 Department of Biochemistry, Molecular Biology, and Biophysics, University of Minnesota, \\ Minneapolis, MN 55455, USA; bsven@ddt.umn.edu (B.S.); sacarlson@mcw.edu (S.F.C.); \\ corne002@umn.edu (R.L.C.); ddt@umn.edu (D.D.T.) \\ 2 Krannert Institute of Cardiology, Department of Medicine, Indiana University School of Medicine, \\ Indianapolis, IN 46202, USA; zhechen@iu.edu \\ 3 McPhail Equine Performance Center, Department of Large Animal Clinical Sciences, \\ College of Veterinary Medicine, Michigan State University, East Lansing, MI 48823, USA \\ * Correspondence: jma@ddt.umn.edu (J.M.A.); valbergs@msu.edu (S.J.V.) \\ + Co-senior authors.
}

check for updates

Citation: Autry, J.M.; Svensson, B.; Carlson, S.F.; Chen, Z.; Cornea, R.L.; Thomas, D.D.; Valberg, S.J.

Sarcoplasmic Reticulum from Horse Gluteal Muscle Is Poised for Enhanced Calcium Transport. Vet. Sci. 2021, 8, 289. https://doi.org/ $10.3390 /$ vetsci 8120289

Academic Editor: Antonio Humberto Hamad Minervino

Received: 20 October 2021

Accepted: 17 November 2021

Published: 23 November 2021

Publisher's Note: MDPI stays neutral with regard to jurisdictional claims in published maps and institutional affiliations.

Copyright: (C) 2021 by the authors. Licensee MDPI, Basel, Switzerland. This article is an open access article distributed under the terms and conditions of the Creative Commons Attribution (CC BY) license (https:/ / creativecommons.org/licenses/by/ $4.0 /)$.

\begin{abstract}
We have analyzed the enzymatic activity of the sarcoplasmic reticulum (SR) $\mathrm{Ca}^{2+}$-transporting ATPase (SERCA) from the horse gluteal muscle. Horses are bred for peak athletic performance yet exhibit a high incidence of exertional rhabdomyolysis, with elevated levels of cytosolic $\mathrm{Ca}^{2+}$ proposed as a correlative linkage. We recently reported an improved protocol for isolating SR vesicles from horse muscle; these horse SR vesicles contain an abundant level of SERCA and only trace-levels of sarcolipin (SLN), the inhibitory peptide subunit of SERCA in mammalian fast-twitch skeletal muscle. Here, we report that the in vitro $\mathrm{Ca}^{2+}$ transport rate of horse SR vesicles is $2.3 \pm 0.7$-fold greater than rabbit SR vesicles, which express close to equimolar levels of SERCA and SLN. This suggests that horse myofibers exhibit an enhanced SR $\mathrm{Ca}^{2+}$ transport rate and increased luminal $\mathrm{Ca}^{2+}$ stores in vivo. Using the densitometry of Coomassie-stained SDS-PAGE gels, we determined that horse SR vesicles express an abundant level of the luminal SR $\mathrm{Ca}^{2+}$ storage protein calsequestrin (CASQ), with a CASQ-to-SERCA ratio about double that in rabbit SR vesicles. Thus, we propose that $\mathrm{SR} \mathrm{Ca}^{2+}$ cycling in horse myofibers is enhanced by a reduced SLN inhibition of SERCA and by an abundant expression of CASQ. Together, these results suggest that horse muscle contractility and susceptibility to exertional rhabdomyolysis are promoted by enhanced SR $\mathrm{Ca}^{2+}$ uptake and luminal $\mathrm{Ca}^{2+}$ storage.

Keywords: calcium regulation; calsequestrin; comparative biochemistry; excitation-contraction coupling; exertional rhabdomyolysis; intraluminal protein; ion-motive ATPase; membrane vesicles; regulatory subunit; skeletal muscle
\end{abstract}

\section{Introduction}

Horses are highly susceptible to muscle exertional rhabdomyolysis from a variety of causes, including glycogen storage disorders, malignant hyperthermia, and abnormalities in cytosolic $\mathrm{Ca}^{2+}$ regulation [1]. The horse species has been bred selectively for thousands of years to achieve a remarkable athletic ability, in part conferred by a naturally high proportion (75-95\%) of fast-twitch myofibers in the locomotor muscles that provide powerful contraction and rapid running [2]. Recurrent exertional rhabdomyolysis (RER) is one of the most common causes of poor performance and economic loss in Thoroughbred racehorses [3,4]. The molecular etiology of RER in Thoroughbred racehorses has been proposed to involve defects in excitation-contraction coupling, $\mathrm{SR} \mathrm{Ca}^{2+}$ cycling, electron transport, and mitochondrial protein translation [1,5-8].

Valberg et al. [9] used whole-transcriptome RNA shotgun sequencing (RNA-seq) to determine the amino acid sequence and transcription level of $\mathrm{Ca}^{2+}$ regulatory proteins 
in Thoroughbred muscle. These proteins include the sarcoplasmic reticulum (SR) $\mathrm{Ca}^{2+}$ transporting ATPase protein $($ SERCA $=110 \mathrm{kDa})$, the regulatory peptide subunits sarcolipin $(\mathrm{SLN}=3.3 \mathrm{kDa})$, and phospholamban $(\mathrm{PLN}=5.2 \mathrm{kDa})$, plus the luminal $\mathrm{Ca}^{2+}$-storage protein calsequestrin (CASQ $\sim 55 \mathrm{kDa}$ ). RNA-seq determined that (i) the SLN transcript is the predominant regulatory peptide expressed in horse muscle, as compared to the PLN transcript, and (ii) the $S L N$ transcript is expressed at a many-fold greater level than the ATP2A1 transcript, which produces the SERCA1 protein expressed in fast-twitch skeletal muscle (hereafter, SERCA1 will be referred to as 'SERCA') [9,10]. RNA-seq also determined that the gene expression of the CASQ1 transcript, which produces the fast- and slow-twitch skeletal muscle protein isoform (hereafter referred to as CASQ) is downregulated in the gluteal muscle of male or female horses with RER, as compared to healthy male or female horses (controls). Furthermore, expression of the CASQ transcript was downregulated to a greater extent in the gluteal muscle of male horses with RER compared to female horses with RER [9]. Thus, RNA-seq results identified potential molecular mechanisms that contribute to the high performance of horse muscle and suggested a possible need for gender-specific pharmacophore therapies for horse RER susceptibility.

We recently developed an improved protocol for the purification of SR vesicles from horse muscle, which provides 5-25-fold greater $\mathrm{Ca}^{2+}$-activated ATPase activity than previously reported for SERCA in horse muscle SR vesicles [11]. This new horse SR prep allowed for an improved characterization of the protein profile of horse SR using quantitative immunoblotting and Stains-all in-gel staining [11]. The RNA-seq data demonstrated the supra-abundant expression of the SLN transcript in horse muscle, yet quantitative immunoblotting detected only a trace level of SLN peptide in horse SR vesicles, as compared to SERCA protein (0.06 SLN/SERCA mol/mol) [9-11]. SLN is the primary regulatory peptide of SERCA expressed in skeletal muscles from larger mammals, e.g., rabbits, dogs, pigs, and humans [12-15]. SLN protein expression has been reported at a significant level in only a few mouse skeletal muscles, for example, in the slow-twitch soleus muscle of adult mice, in the fast-twitch gastrocnemius muscle of aging mice, and in some other muscle types in atrophy mouse models [16]. In mice, other regulatory peptides have been shown to regulate SERCA activity. Therefore, the use of SLN knockout transgenic mice as experimental model muscles to study the lack of SLN is limited. Thus, an investigation of $\mathrm{Ca}^{2+}$ uptake activity using a SR skeletal muscle system that lacks known SERCA inhibitors, i.e., the minimal or insignificant expression of SLN, PLB, and MRLN, has been limited to in vitro assays of $\mathrm{Ca}^{2+}$-activated ATPase activity by SR vesicles purified from horse gluteus [10,11].

The general consensus is that SLN inhibits SERCA activity via multiple enzymatic mechanisms: by decreasing the maximal velocity $\left(\mathrm{V}_{\max }\right)$, by decreasing the apparent $\mathrm{Ca}^{2+}$ binding affinity $\left(1 / \mathrm{K}_{\mathrm{Ca}}\right)$, by decreasing ATP binding affinity $\left(1 / \mathrm{K}_{\mathrm{ATP}}\right)$, and by decreasing the number of $\mathrm{Ca}^{2+}$ ions transported per ATP molecule hydrolyzed (coupling ratio) below the optimal $\mathrm{Ca}^{2+} /$ ATP coupling ratio of two [17-23]. The SLN inhibition of SERCA activity is relieved in part by SLN phosphorylation or de-acylation [24-26]. In a mouse slow-twitch muscle (soleus and red gastrocnemius), the genetic knockout of SLN results in an enhanced ATP-dependent $\mathrm{Ca}^{2+}$ uptake by SERCA [27]. In patients with atrial fibrillation (AFib) or heart failure with preserved ejection fraction (HFpEF), a decreased expression of SLN correlates with an increased $\mathrm{Ca}^{2+}$ uptake in atrial SR; however, it is unknown if decreased SLN inhibition and concomitant SERCA activation are compensatory or causative in the progression of human cardiovascular disease [28,29].

Aberrant $\mathrm{Ca}^{2+}$ signaling from SR $\mathrm{Ca}^{2+}$ stores in skeletal myocytes has been identified in pig malignant hyperthermia $(\mathrm{MH})$ due to a natural mutation of the ryanodine receptor $\mathrm{SR} \mathrm{Ca}^{2+}$ release channel (RYR) and also in a mouse genetic model of increased sarcolemmal $\mathrm{Ca}^{2+}$ entry that leads to an SR store overload-induced $\mathrm{Ca}^{2+}$ release (SOICR) through RYR [30-32]. Mutations in the luminal $\mathrm{Ca}^{2+}$ storage protein calsequestrin (CASQ) result in catecholaminergic polymorphic ventricular tachycardia (CPVT) [33,34]. Thus, the rate of SERCA $\mathrm{Ca}^{2+}$ transport activity, the level of SLN inhibition, and the amount of luminal SR 
$\mathrm{Ca}^{2+}$ are critical for the coordinated tuning of $\mathrm{Ca}^{2+}$ cycling kinetics in myocytes, thereby matching the physiological requirements for the contraction and relaxation of each specific muscle type.

In the present study, we used biochemical approaches to investigate $\mathrm{Ca}^{2+}$ transport regulation in horse gluteus, a predominant locomotor muscle. The enzymatic properties of SERCA in horse SR vesicles were compared to SERCA in rabbit SR vesicles, which are the standard experimental model for examining SR function, as previously discussed [11]. These studies identified a high rate of SERCA $\mathrm{Ca}^{2+}$ transport activity (possibly due to the decreased SLN expression) and a higher total luminal $\mathrm{Ca}^{2+}$ accumulation (possibly due to the enhanced CASQ expression) in horse SR. These findings were interpreted in light of the high susceptibility of horses to exertional rhabdomyolysis. We propose that comparative studies of biochemical regulation of SR enzymes will increase the broader understanding of the selective adaptation of horse muscle, with a specific focus on species-dependent performance and disease.

\section{Materials and Methods}

\subsection{Materials}

The Enzyme Commission (EC) number of SERCA is 7.2.2.10 [35]. Proteinase K (EC 3.4.21.64) and standard chemicals were purchased from Sigma-Aldrich Corporation (St. Louis, MO, USA). The ${ }^{45} \mathrm{Ca}\left(\mathrm{CaCl}_{2}\right)$ isotope was purchased from New England Nuclear Corporation (Billerica, MA, USA).

\subsection{Animals}

Muscle samples were obtained from four horses (Equus caballus) that were donated to the University of Minnesota for euthanasia due to orthopedic disease; these horses had healthy musculoskeletal systems. Table S1 lists details on the following horses examined in this study: three castrated males (two Quarter Horses and one Thoroughbred) and one female (Quarter Horse). The horses examined in this study were pastured horses donated to the University because of chronic lameness. They had no history of muscle disease and were of ages ranging from 10 to 18 years (Table S1). The horse owners provided written consent for obtaining muscle samples for this research.

Muscle samples were also obtained from six New Zealand White rabbits that were provided by the University of Minnesota Research Animal Resources Facility. The New Zealand White rabbits examined in this study were junior does of age $\leq 6 \mathrm{mo}$.

The University of Minnesota Research Animal Resources Facility complies with the USDA Animal Welfare Act Regulations and the NIH Public Health Service Policy on Humane Care and Use (Animal Welfare Assurance approval A3456-01 via the NIH Office of Laboratory Animal Welfare). The University of Minnesota received accreditation renewal from the Association for Assessment and Accreditation of Laboratory Animal Care (AAALAC) in November 2015. All animal research was reviewed and approved by the Institutional Animal Care and Use Committee (IACUC) at the University of Minnesota, with IACUC protocol \# 1511-33199A for horses and IACUC protocol \# 1611-34327A for rabbits. Palliative care and euthanasia protocols [9-11] were consistent with guidelines from the American Veterinary Medical Association.

\subsection{Purification of SR Vesicles from Horse and Rabbit Muscle}

SR vesicles from horse gluteus (predominantly fast-twitch myofibers) and rabbit skeletal muscle (fast-twitch muscles pooled from back and legs) were isolated using mechanical homogenization and differential centrifugation. Horse SR vesicles are defined as the pellet from the centrifugation of a gluteal muscle homogenate at $10,000 \times \mathrm{g}$ for $20 \mathrm{~min}$ at $4{ }^{\circ} \mathrm{C}$, following an initial clarification spin of $3800 \times g$ for $20 \mathrm{~min}$ at $4{ }^{\circ} \mathrm{C}$. Rabbit SR vesicles are defined as the pellet from the centrifugation of a muscle homogenate (pooled back muscle and hind leg muscle) at $23,000 \times g$ for $60 \mathrm{~min}$, following initial clarification spins of $4000 \times g$ 
for $20 \mathrm{~min}$ at $4{ }^{\circ} \mathrm{C}$ and $11,800 \times g$ for $20 \mathrm{~min}$ at $4{ }^{\circ} \mathrm{C}[10,11,36]$. The pooled muscle tissue from the rabbit was white colored (indicating a fast-twitch muscle).

\subsection{SDS-PAGE and Coomassie Densitometry}

SDS-PAGE of SR vesicles was performed as reported previously [10,11,37]. Proteins were stained in-gel with Coomassie blue R-250. A GelDoc EZ imaging system with the software Image Lab 5.0 (Bio-Rad Laboratories Incorporated; Hercules, CA, USA) was used to scan Coomassie-stained gels and to quantitate the relative absorbance of each Coomassie-stained protein band. Camera exposure time was optimized to prevent pixel saturation of the absorbance intensity for each Coomassie-stained protein band.

\subsection{Oxalate-Facilitated ${ }^{45} \mathrm{Ca}^{2+}$ Transport Assay}

$\mathrm{Ca}^{2+}$ transport by SR vesicles was measured using a filtration assay with a ${ }^{45} \mathrm{Ca}$ radioactive tracer $[37,38]$. Assays were conducted at $25^{\circ} \mathrm{C}$ with $10 \mu \mathrm{g}$ of SR protein in a 1-milliliter solution containing $100 \mathrm{mM} \mathrm{KCl}, 3.3 \mathrm{mM} \mathrm{MgCl}$, $3.0 \mathrm{mM} \mathrm{Na} 2 \mathrm{ATP}, 10 \mathrm{~mm}$ $\mathrm{K}_{2}$-oxalate, $5 \mathrm{mM} \mathrm{NaN}_{3}$, and $50 \mathrm{mM}$ MOPS ( $\mathrm{pH}$ 7.0). The addition of $2 \mathrm{mM}$ EGTA and $1.8 \mathrm{mM} \mathrm{CaCl}_{2}$ (containing trace amounts of ${ }^{45} \mathrm{Ca}$ ) was used to produce an ionized $\mathrm{Ca}^{2+}$ concentration $\left(\left[\mathrm{Ca}^{2+}\right]_{\mathrm{i}}\right)$ of $2.4 \mu \mathrm{M}$, i.e., a $\mathrm{V}_{\max }$ assay with a saturating concentration of substrates $\mathrm{Ca}^{2+}, \mathrm{Mg}^{2+}$, and ATP. Transport assays were started by the addition of protein samples to reaction tubes. $\mathrm{Ca}^{2+}$ transport was terminated at serial time intervals by vacuum filtering $100 \mu \mathrm{L}$ of assay solution (i.e., $1 \mu \mathrm{g}$ of SR protein) through a HA-type glass-fiber filter with a 0.45-micrometer pore size (Millipore Corporation; Burlington, MA), which was washed twice with $5 \mathrm{~mL}$ of ice-cold $150 \mathrm{mM} \mathrm{NaCl}$ solution. The loading of ${ }^{45} \mathrm{Ca}$ inside SR vesicles was determined by liquid scintillation counting. Background ${ }^{45} \mathrm{Ca}$ binding (defined as a glass-fiber filter blank loaded with $1 \mu \mathrm{g}$ of SR protein in the absence of ATP) was subtracted from the experimental values (the glass-fiber filter sample loaded with $1 \mu \mathrm{g}$ of SR protein in the presence of ATP) to yield the amount of ATP-dependent $\mathrm{Ca}^{2+}$ transport by SR vesicles.

\subsection{Proteinase K Assay of SERCA Conformational States}

Controlled proteolysis by Proteinase K (ProtK) was used to assess the ligand-dependent conformational state of the horse and rabbit SERCA $[39,40]$. The standard assay solution contained $50 \mathrm{mM} \mathrm{NaCl}, 0.5 \mathrm{mM} \mathrm{MgCl}_{2}$, and $20 \mathrm{mM}$ MOPS (pH 7.0), with an addition of either $0.1 \mathrm{mM} \mathrm{CaCl}_{2}$ (to stabilize the E1•2 $\mathrm{Ca}^{2+}$ biochemical state) or $2 \mathrm{mM}$ EGTA and $1 \mu \mathrm{M}$ TG (to stabilize the $\mathrm{Ca}^{2+}$-free E2•TG biochemical state) [41]. SR vesicles at $500 \mu \mathrm{g} / \mathrm{mL}$ were incubated with $12.5 \mu \mathrm{g} / \mathrm{mL}$ ProtK (40/1 wt/wt protein) for $15 \mathrm{~min}$ at $23^{\circ} \mathrm{C}$. Proteolysis was stopped by the addition of ice-cold trichloroacetic acid (TCA at $2.5 \% \mathrm{wt} / \mathrm{vol}$ ), followed by the addition of a Laemmli sample solution (final concentration of $1.1 \%$ lithium dodecyl sulfate). SR samples were electrophoresed through a 4-15\% Laemmli gel. Non-proteolyzed proteins and proteolytic fragments were stained in-gel with Coomassie blue. The ProtKmediated cleavage pattern of SERCA (e.g., the 95 and $83 \mathrm{kDa}$ fragments) was imaged using the in-gel absorbance intensity of Coomassie-stained bands detected using a Bio-Rad GelDoc EZ imaging system.

\subsection{Experimental Design, Statistical Analysis, and Data Presentation}

Biochemical assays were performed using independent SR vesicle preparations from $\mathrm{N}=2-4$ horses and $\mathrm{N}=3-6$ rabbits. Scientists were not blinded to sample identity during data acquisition or analysis. Data are reported as mean \pm standard error (SEM). Data graphs were generated using Origin 2015 software (OriginLab Corporation; Northampton, MA, USA). For statistical difference determination, we used two-way, unpaired Student's $t$-test. Significance was accepted at $p<0.05$. 


\section{Results}

3.1. Horse SR Vesicles Contain an Abundant Amount of SERCA Protein, Although at a Lower Level Than Rabbit SR Vesicles

We recently developed a new protocol for isolating SR vesicles from horse muscle with $\mathrm{Ca}^{2+}$-dependent ATPase activity by SERCA that was $>$ five-fold greater than previously reported [11]. Here, electrophoretic analysis was performed to corroborate the identification of SR protein distribution in horse muscle SR (Figure 1). Coomassie densitometry was used to determine that $\mathrm{SR}$ vesicles from the horse gluteal muscle express $\sim 55 \%$ less ( $53 \pm 7 \%$, $p=0.005$ ) of the relative content of SERCA compared to rabbit SR (Figure 1, Table S2), although this determination may be a slight overestimate, since horse SR vesicles probably contain a small amount of GP and/or additional proteins that co-migrate with SERCA at $\sim 100 \mathrm{kDa}$ on SDS-PAGE [11]. Our prior quantitative immunoblotting compared the relative amount of SERCA protein in SR vesicles from the horse versus rabbit muscle. For standardization, the SERCA content of SR vesicles from rabbit fast-twitch (white) muscle has been determined to be 55-70\% of the total protein (weight/weight), i.e., $5.0-6.4 \mathrm{nmol}$ SERCA per $\mathrm{mg}$ of the total SR protein [41-44]. Immunoblotting with anti-SERCA1 mAb VE12 ${ }_{1} G 9$ demonstrated that SR vesicles from the horse gluteal muscle express $\sim 35 \%$ of the relative amount of SERCA1 as compared to rabbit SR, although this is probably a slight underestimate of the total SERCA content (because horse SR also contains a minor amount of SERCA2, which is incompatible with the use of anti-SERCA1 mAb VE12 ${ }_{1}$ G9) $[9,11]$.

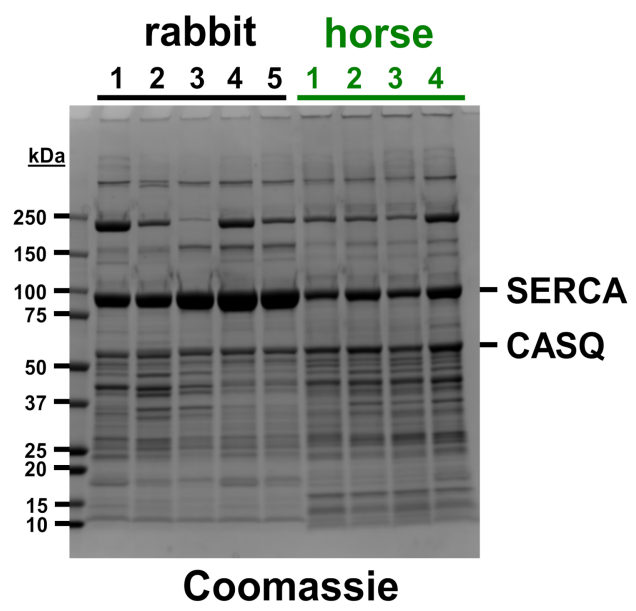

Figure 1. Coomassie gel of rabbit and horse SR vesicles. Five rabbit SR preps and four horse SR preps were electrophoresed on Laemmli SDS-PAGE and stained with Coomassie blue. The amount of protein loaded was $15 \mu \mathrm{g}$ per lane. The molecular mass of protein gel markers $(\mathrm{kDa})$ is indicated on the left. Gel bands of SERCA and CASQ are identified on the right.

Despite the minor limitation of each gel-based method, quantitative immunoblotting and Coomassie densitometry are two orthogonal assays that provide similar results, indicating that horse SR vesicles express $35-55 \%$ of the SERCA content of rabbit SR vesicles. Based on these two detection methods, we estimate that horse SR contains $45 \pm 7 \%$ of the SERCA level of rabbit SR. Assuming that (i) the expression level of SERCA in rabbit SR is $6.0 \mathrm{nmol}$ SERCA/mg SR protein, a commonly used mean value, and (ii) horse SR contains $45 \pm 7 \%$ of the amount of SERCA protein as rabbit SR, then the density of SERCA expressed in horse SR is calculated as $2.7 \pm 0.6 \mathrm{nmol}$ SERCA $/ \mathrm{mg}$ SR protein.

Previously, it has been determined that a rabbit extensor digitorum longus muscle homogenate contains $0.4 \pm 0.1$ SLN/SERCA (molar ratio) and a rabbit soleus muscle contains $0.9 \pm 0.2$ [13]. Additionally, SR purified from the pooled rabbit fore and hind leg muscles SR contains 1.2 SLN/SERCA [44] and the contralateral fast-twitch skeletal muscle contains 0.8 SLN/SERCA (molar ratios) [17]. Furthermore, we have used quantitative immunoblotting with purified protein standards to determine that horse SR vesicles express SLN/SERCA at a molar ratio of 0.06 [10]. These previous immunoblot evaluations of the 
SLN content of the horse SR used a custom antibody raised against a six-residue peptide corresponding to the N-terminus of SLN from a horse. This antibody against the horse sequence detected horse SLN, and a low SLN/SERCA molar ratio in the horse gluteal muscle SR and homogenate [11]. For the present study, we made a new anti-SLN antibody based on the horse N-terminal sequence. Using this antibody, we confirmed that the SR vesicles used in this study contain only trace levels of SLN (Figure S1), as shown before $[10,11]$.

Multiple SR preps from individual horses and rabbits were assayed using densitometry and immunoblotting, demonstrating that there are only slight variations in the high content of key SR proteins (e.g., SERCA and CASQ) and in the low content of contaminating proteins (e.g., myosin) among the multiple SR preparations from each animal (Figure 1). Our next goals are to increase the purity of horse SR vesicles and to increase the number of SR preps purified from horse and rabbit muscles, in order to account for individual variation(s) in muscle proteogenomics. In this report, we detected a small amount of uncertainty in the measured SERCA content (Table S2), yet, as demonstrated below, this uncertainty does not affect the reported results; for example, horse SR vesicles have an enhanced oxalate-facilitated $\mathrm{Ca}^{2+}$ transport compared to rabbit $\mathrm{SR}$ vesicles, as determined even without normalization to SERCA content.

\subsection{Horse SR Vesicles Contain an Abundant Level of CASQ Protein, Similar to Rabbit SR Vesicles}

CASQ is a high-capacity $\mathrm{Ca}^{2+}$-binding protein enriched in the SR lumen SR. The CASQ1 isoform is expressed in fast-twitch skeletal muscles such as horse gluteus and rabbit leg and back muscles, plus mammalian slow-twitch skeletal muscles $[9,11,45,46]$. The Coomassie staining of the sets of horse preps and rabbit preps analyzed in this study indicates that horse SR contains $\sim 20 \%$ more CASQ protein than rabbit SR (Figure 1, Table S2). SDS-PAGE gels labeled with the Stains-all dye corroborated similar levels of CASQ protein expression in horse and rabbit SR [11], assuming that horse and rabbit CASQ orthologs bind the Stains-all dye with similar affinity and metachromatic effect, per molecular electronegativity. Both horse and rabbit CASQ1 have the same predicted isoelectric point of 3.8, as determined using the Isoelectric Point Calculator program [47]. The CASQ-to-SERCA ratio in horse SR vesicles $(0.55 \pm 0.01)$ is $\sim 2.25$-fold greater $(p=0.0001)$ than in rabbit SR vesicles $(0.24 \pm 0.03)$, as determined using in-gel Coomassie densitometry (Figure 1, Table S2). We propose that the relatively high level of CASQ protein in horse SR vesicles contributes to the increased SR $\mathrm{Ca}^{2+}$ cycling in vivo and enhanced muscular performance in horses.

\subsection{Horse SR Vesicles Show Greater ATP-Dependent $\mathrm{Ca}^{2+}$ Transport Than Rabbit SR Vesicles}

We used our new protocol for isolating horse SR vesicles [11], which show greatly enhanced $\mathrm{Ca}^{2+}$-ATPase activity, to assess $\mathrm{Ca}^{2+}$ transport by SERCA in horse SR (Figures 1 and 2). ATP-dependent $\mathrm{Ca}^{2+}$ transport was measured using a radiometric filtration assay. ${ }^{45} \mathrm{Ca}^{2+}$ transport was measured at $25^{\circ} \mathrm{C}$ under the $\mathrm{V}_{\max }$ condition, i.e., in the presence of the following saturating concentrations of substrates: $3 \mathrm{mM} \mathrm{ATP}, 3.3 \mathrm{mM} \mathrm{MgCl}$, and an ionized $\mathrm{Ca}^{2+}$ concentration $\left(\left[\mathrm{Ca}^{2+}\right]_{\mathrm{i}}\right.$ ) of $\sim 2.4 \mu \mathrm{M}$ (which was set using an EGTA $/ \mathrm{Ca}^{2+}$ buffering system). Oxalate and azide were added at $5 \mathrm{mM}$ each. Oxalate is a $\mathrm{Ca}^{2+}$-precipitating anion that diffuses into SR vesicles through SR-specific anion/oxalate channels, and thus an oxalate was added to the ${ }^{45} \mathrm{Ca}^{2+}$ transport assay to remove the product-inhibition of SERCA using a high concentration of accumulated luminal $\mathrm{Ca}^{2+}[48-50]$. Due to the high density of SERCA in muscle SR ( 33,000 SERCA molecules per membrane $\left.\mu \mathrm{m}^{2}\right)$ [51], the lumen of SR becomes saturated with $\mathrm{Ca}^{2+}(>1 \mathrm{mM})$ within 1-2 turnover cycles of SERCA molecules, as assessed using in vitro assays of $S R$ vesicles and using myocyte-based relaxation assays in the absence of an oxalate $[52,53]$. The addition of oxalate to in vitro assays allows $\mathrm{Ca}^{2+}$ transport by SERCA in SR vesicles to proceed for minutes, instead of second(s), thereby providing a steady-state biochemical measurement of SERCA activity (e.g., in vitro $\mathrm{V}_{\max }$ assay, as reported in Figure 2 here). 


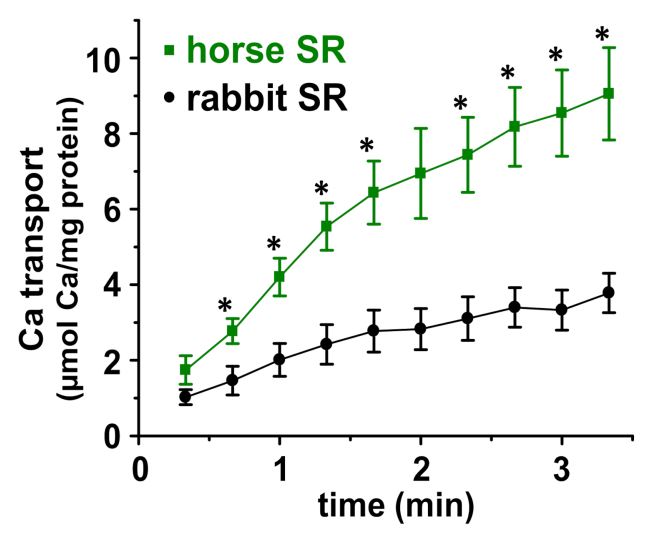

Figure 2. Calcium transport by SR vesicles purified from horse or rabbit muscle. ${ }^{45} \mathrm{Ca}$ transport activity was measured at $25{ }^{\circ} \mathrm{C}$ in the presence of the $\mathrm{Ca}^{2+}$-precipitating anion oxalate, with saturating concentration of substrates $\left(\mathrm{Ca}^{2+}, \mathrm{Mg}^{2+}\right.$, and ATP), thereby providing a steady-state $\mathrm{V}_{\text {max }}$ assay. $n=4-5$ for horse and $n=5$ for rabbit SR. * significantly different between horse and rabbit using unpaired Student's $t$-test, $p<0.05$.

Oxalate-facilitated ${ }^{45} \mathrm{Ca}^{2+}$ transport assays have been optimized extensively for SR vesicles, and the current study of SERCA in horse SR vesicles is based on insights reported by these foundational studies $[36,48,49,53,54]$. Under the assay conditions used in the present study (see Section 2.5), the $\mathrm{Ca}^{2+}$ uptake by SR vesicles from horse muscle (i.e., the $10,000 \times g$ pellet) is specific to SR vesicles, because (i) $\mathrm{Ca}^{2+}$ uptake by mitochondria is inhibited by the addition of azide, which collapses the electric potential of the mitochondrial inner membrane [48], and because (ii) the $\mathrm{Ca}^{2+}$ uptake by sarcolemmal (SL) vesicles is not facilitated by the addition of oxalate, since SL vesicles lack the SR anion/oxalate channel [49]. The specificity of ATP-mediated $\mathrm{Ca}^{2+}$ transport by SERCA was further demonstrated by control experiments in (i) the absence of ATP, which eliminated $>95 \%$ of the $\mathrm{Ca}^{2+}$ transport by horse SR vesicles, and (ii) the presence of thapsigargin (TG), a SERCA-specific inhibitor [55] that eliminated $>95 \%$ of the $\mathrm{Ca}^{2+}$ uptake by horse SR vesicles.

The in vitro ${ }^{45} \mathrm{Ca}^{2+}$ filtration assay demonstrated that the initial rate of $\mathrm{Ca}^{2+}$ transport by horse and rabbit SR vesicles is linear for $\sim 60-80 \mathrm{~s}$ at $25^{\circ} \mathrm{C}$ (Figure 2). Using linear regression of four time points $(0,20,40$, and $60 \mathrm{~s})$, horse SR vesicles exhibit a $\mathrm{Ca}^{2+}$ transport rate of $4.2 \pm 0.7 \mu \mathrm{mol} \mathrm{Ca}{ }^{2+} / \mathrm{mg}$ protein $/ \mathrm{min}$ (i.e., international unit, IU), while rabbit SR vesicles exhibit a $\mathrm{Ca}^{2+}$ transport rate of $1.8 \pm 0.5 \mathrm{IU}$ (Figure 2). These assay conditions, via an oxalate-facilitated uptake, demonstrated that horse SR vesicles show a $2.3 \pm 0.7-$ fold greater rate of $\mathrm{Ca}^{2+}$ transport than rabbit SR vesicles, even though horse SR vesicles contain $45 \pm 7 \%$ of the SERCA protein content of rabbit SR vesicles, as determined using Coomassie densitometry (Figure 1) and quantitative immunoblotting [11]. Similarly, horse $\mathrm{SR}$ vesicles show $52 \%$ of the $\mathrm{Ca}^{2+}$-activated ATPase activity compared to rabbit $\mathrm{SR}$ vesicles (Table 1) [11].

The amount of oxalate-facilitated $\mathrm{Ca}^{2+}$ accumulation by horse and rabbit $\mathrm{SR}$ vesicles continued to increase until $\sim 5 \mathrm{~min}$, when the rate of net ${ }^{45} \mathrm{Ca}^{2+}$ uptake reached zero, i.e., a plateau of the steady-state accumulation of ${ }^{45} \mathrm{Ca}^{2+}$, where the uptake and release/leak rates are equal. At $\sim 5-10 \mathrm{~min}$, the total amount of accumulated intravesicular $\mathrm{Ca}^{2+}$ began to decrease, probably due to the disruption of SR vesicle integrity by the growth of luminal $\mathrm{Ca}^{2} /$ oxalate deposits sized beyond a vesicular capacity.

The robust rate of $\mathrm{Ca}^{2+}$ transport by horse SR vesicles indicated that horse SR vesicles in the 10KP fraction, isolated by our newly developed protocol $[10,11]$, are mostly intact and sealed. Table 1 reports that the $\mathrm{Ca}^{2+}$ transport $\mathrm{V}_{\max }$ rate of $\mathrm{SR}$ vesicles isolated from horse muscle [5,56-59]. Here, we show that the $\mathrm{Ca}^{2+}$ transport $\mathrm{V}_{\max }$ rate by horse $\mathrm{SR}$ vesicles, as isolated using the improved protocol [10,11], is 8-23-fold greater than the $\mathrm{Ca}^{2+}$ transport $V_{\max }$ rate of horse SR vesicles isolated by previously reported protocols (Table 1). Thus, we have demonstrated that SR vesicles from horse muscle provide a useful system for studying $\mathrm{Ca}^{2+}$ transport by horse SERCA. We propose that the high $\mathrm{V}_{\max }$ rate of $\mathrm{Ca}^{2+}$ 
transport by horse SERCA is facilitated by the lack of SLN regulatory peptides [10,11] and by the abundance of CASQ protein in horse SR (Figure 1) [9,11].

Table 1. Reported $\mathrm{Ca}^{2+}$-ATPase and $\mathrm{Ca}^{2+}$ transport activities in SR vesicles purified from horse muscle. Published results of horse SERCA activities are listed from studies using unfractionated SR vesicles purified from horse muscle, as assessed using the oxalate-facilitated ${ }^{45} \mathrm{Ca}^{2+}$ transport assay (Figure 2) or the ionophore-facilitated $\mathrm{Ca}^{2+}$-activated ATPase assay [11]. Our improved protocol for isolating horse SR vesicles from gluteal muscle provided a $\mathrm{Ca}^{2+}$ transport activity of $4.2 \pm 0.7 \mathrm{IU}$ at $25{ }^{\circ} \mathrm{C}$ and a $\mathrm{Ca}^{2+}$-activated ATPase activity of $4.0 \pm 0.4 \mathrm{IU}$ at $37^{\circ} \mathrm{C}$. Prior to this study, the maximum reported activities of horse SR vesicles were an oxalate-facilitated $\mathrm{Ca}^{2+}$ transport activity of $0.55 \pm 0.16 \mathrm{IU}$ at $37^{\circ} \mathrm{C}$ and an ionophore-facilitated $\mathrm{Ca}^{2+}$-activated ATPase of $0.73 \pm 0.14 \mathrm{IU}$ at $37^{\circ} \mathrm{C}$. For comparison, Table 1 also lists the $\mathrm{Ca}^{2+}$ transport and $\mathrm{Ca}^{2+}$-ATPase activities of unfractionated SR vesicles purified from rabbit fast-twitch muscle, assayed under the same conditions used for horse SR vesicles in this study (Figure 2) and [11], respectively.

\begin{tabular}{|c|c|c|c|}
\hline SR & $\begin{array}{l}\mathrm{Ca}^{2+} \text { Transport (IU) } \\
+ \text { Oxalate }\end{array}$ & $\begin{array}{l}\mathrm{Ca}^{2+} \text {-ATPase (IU) } \\
+ \text { A23187 }\end{array}$ & $\begin{array}{c}\text { Transport/ATPase } \\
\text { (IU/IU) }\end{array}$ \\
\hline $\begin{array}{l}\text { Horse (Anal. Biochem. } 2020^{\mathrm{c}}, \\
\text { this study }{ }^{\mathrm{d}} \text { ) }\end{array}$ & $4.2 \pm 0.7^{\mathrm{d}}$ & $4.0 \pm 0.4^{c}$ & $1.05 \pm 0.20$ \\
\hline Horse (Eq. Vet. J. Suppl. $\left.1998^{\mathrm{e}}\right)$ & $0.18 \pm 0.02$ & $0.16 \pm 0.01$ & $1.13 \pm 0.13$ \\
\hline Horse (J. Anim. Sci. $1995^{\mathrm{f}}$ ) & $0.19 \pm 0.02$ & $0.16 \pm 0.01$ & $1.19 \pm 0.12$ \\
\hline Horse (J. Appl. Physiol. 1989 g) & $0.55 \pm 0.16$ & $0.73 \pm 0.14$ & $0.75 \pm 0.35$ \\
\hline Rabbit ${ }^{h}$ & $1.8 \pm 0.5^{\mathrm{d}}$ & $7.6 \pm 0.5^{c}$ & $0.24 \pm 0.14$ \\
\hline
\end{tabular}

a Oxalate, a $\mathrm{Ca}^{2+}$-precipitating anion, was added to the ${ }^{45} \mathrm{Ca}^{2+}$ transport assay in order to trap the accumulated intravesicular $\mathrm{Ca}^{2+} .{ }^{\mathrm{b}} \mathrm{A} 23187, \mathrm{a} \mathrm{Ca}^{2+}$ ionophore, was added to the $\mathrm{Ca}^{2+}$-activated ATPase assay in order to release the accumulated intravesicular $\mathrm{Ca}^{2+} .{ }^{\mathrm{c}}$ Data are from Autry et al. [11]. ${ }^{\mathrm{d}}$ This study (Figure 2), respectively. e Wilson et al., Eq. Vet. J. Suppl. 1998 [59]. ${ }^{\mathrm{f}}$ Wilson et al., J. Anim. Sci. 1995 [58]. g Byrd et al., J. Appl. Physiol. 1989 [56]. ${ }^{\text {h }}$ SR vesicles from rabbit fast-twitch skeletal muscle purified by slight adaptation [11] of the protocol from Ikemoto et al., J. Biol. Chem. 1971 [36].

\subsection{Horse and Rabbit SERCA Show Similar Temperature-Dependence of $\mathrm{Ca}^{2+}$-Activated ATPase Activity}

The internal temperature of actively contracting horse muscle is $42-44{ }^{\circ} \mathrm{C}$ [60]. Since temperature controls the structure and activity of enzymes, we compared the temperature dependence of the $\mathrm{Ca}^{2+}$-activated ATPase $\mathrm{V}_{\max }$ activity for SERCA in horse and rabbit SR (Figure 3). With a saturating concentration of substrates, both horse and rabbit SERCA show a biphasic effect of enzyme activation and inactivation, with a robust $\sim$ six-fold increase in activity when raising the temperature from 20 to $45^{\circ} \mathrm{C}$ using $5{ }^{\circ} \mathrm{C}$ steps. This is followed by a steep $\sim 19$-fold decrease in activity when raising the temperature from 45 to $50{ }^{\circ} \mathrm{C}$ (Figure 3). The $50 \%$ transition temperature from peak activity to thermal inactivation $\left(\mathrm{T}_{\mathrm{i}}\right)$ is $\sim 48^{\circ} \mathrm{C}$ for both horse and rabbit SERCA. For comparison, rat SERCA in SR vesicles from rat skeletal muscle exhibits a $50 \%$ thermally induced inactivation at $\mathrm{T}_{\mathrm{i}}=47 \pm 0.7^{\circ} \mathrm{C}$ [61]. The similarities in the thermal activation and the inactivation of SERCA from horse and rabbit muscle indicate a similarity in the protein structure and function of the two orthologs, such that global structure and temperature-dependence probably do not account for the increased relative rate of $\mathrm{Ca}^{2+}$ transport by horse SERCA. The temperature-dependence assay also demonstrates that horse SERCA in the presence of a low level of horse SLN shows a similar biphasic thermal profile of $\mathrm{Ca}^{2+}$-ATPase activity to rabbit SERCA in the presence of an approximately equimolar level of rabbit SLN $[17,44]$. We propose that the robust $\mathrm{Ca}^{2+}$ transport activity of SERCA in horse SR vesicles compared to rabbit SERCA is due, in part, to the lack of SLN inhibition, and possibly due to specific variations in the amino acid sequence and local secondary structural elements of horse SERCA. 


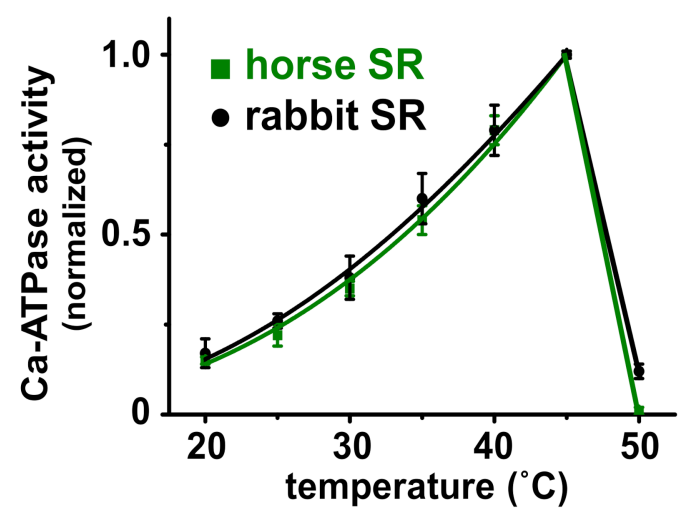

Figure 3. Horse and rabbit SERCA show a similar temperature dependence of $\mathrm{Ca}^{2+}$-activated ATPase activity. SR vesicles from horse and rabbit muscle were assayed for ATP hydrolysis in the presence of a saturating concentration of substrates $\left(100 \mu \mathrm{M} \mathrm{Ca}^{2+}\right.$ and $5 \mathrm{mM} \mathrm{Mg}$-ATP), in the presence of $\mathrm{Ca}^{2+}$ ionophore A23187.

\subsection{Horse and Rabbit SERCA Show Similar $\mathrm{Ca}^{2+}$-Dependent Cleavage by Proteinase $\mathrm{K}$}

To assess the structural dynamics of horse SERCA, we utilized controlled Proteinase K (ProtK) cleavage to assess the conformation-specific cleavage of SERCA. ProtK shows selectivity for accessible sites in protein segments that exhibit enhanced structural dynamics prior to ProtK binding and cleavage. ProtK cleaves SERCA at Actuator domain linker segments in the membrane/water interfacial boundary $[39,40]$, and these sites have been well characterized for the rabbit SERCA1 protein. In the presence of $\mathrm{Ca}^{2+}\left(\mathrm{E} 1 \bullet 2 \mathrm{Ca}^{2+}\right.$ biochemical state), ProtK cuts rabbit SERCA selectively at residue T242 on stalk segment three leading out of the Actuator domain into transmembrane segment three, yielding a major C-terminal fragment comprising residues 243-994 (molecular mass of $83 \mathrm{kDa}$ ) (Figure 4). In the absence of $\mathrm{Ca}^{2+}(\mathrm{E} 2 \bullet \mathrm{TG}$ biochemical state, stabilized by the inhibitor thapsigargin), ProtK cuts rabbit SERCA selectively at residue L119 on stalk segment two, yielding a major C-terminal fragment comprising residues 120-994 (molecular mass of $95 \mathrm{kDa}$ ), with a low amount of secondary cleavage at T242, i.e., also producing a minor fragment of $83 \mathrm{kDa}$ (Figure 4). As in the amino acid sequence of rabbit SERCA, horse SERCA also encodes residues L119 and T242.

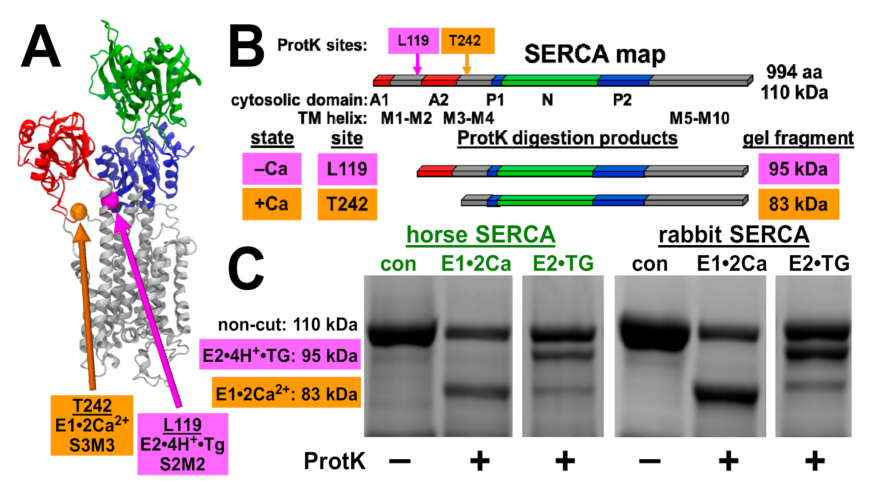

Figure 4. Horse and rabbit SERCA show similar calcium-dependent cleavage by Proteinase K. (A), location of conformation-specific ProtK sites shown in the X-ray crystal structure of rabbit SERCA in the calcium-free E2•TG state (PDB ID code 1IWO [62]). (B), location of conformationspecific ProtK sites in the primary topology map of rabbit SERCA. (C), horse and rabbit SR vesicles were digested with ProtK, and proteolytic fragments of SERCA were analyzed using SDS-PAGE and Coomassie staining. The same cleavage pattern is observed between the horse and the rabbit. The molecular mass of SERCA and diagnostic ProtK fragments are indicated on the left. SERCA samples were electrophoresed on the same Coomassie gel, and the gel slices shown are presented with the same image scale of absorbance intensity for Coomassie-stained bands. 
Here, ProtK digestion demonstrated that horse SERCA shows a similar $\mathrm{Ca}^{2+}$-dependent conformational change as rabbit SERCA, providing similar fragment intensities of the 83 and $95 \mathrm{kDa}$ bands as rabbit SERCA in the presence and absence of $\mathrm{Ca}^{2+}$, respectively. Thus, the ProtK assay demonstrates that horse SERCA in the absence of SLN shows a similar $\mathrm{Ca}^{2+}$-dependent conformation change as rabbit SERCA in the presence of SLN. We propose that (i) the structural dynamics of stalk segments two and three of horse SERCA is similar to that of stalk segments two and three of rabbit SERCA, and (ii) the absence of SLN as a SERCA-bound protein subunit does not affect the equilibrium of $\mathrm{Ca}^{2+}$ bound versus $\mathrm{Ca}^{2+}$ free states of horse SERCA in ligand-induced intermediates, i.e., in a non-cycling enzyme stabilized in E1•2Ca ${ }^{2+}$ or E2•TG. We conclude that the ProtK assay demonstrates similarity in the structural dynamics of horse and rabbit SERCA, suggesting that the lack of SLN in horse SR helps enhance $\mathrm{Ca}^{2+}$ transport by horse SERCA.

As further validation of the new protocol for purification of horse SR, the ProtK assay provides an almost complete digestion of horse and rabbit SERCA (110 kDa bands) in $15 \mathrm{~min}$ at $23^{\circ} \mathrm{C}$; thus, almost all of the SR vesicles in horse and rabbit preps are oriented right-side out, with an extravesicular location of the SERCA headpiece, as expected. We conclude that the reported protocol for isolation of $S R$ vesicles from horse muscle provides a preparation suitable for functional and structural comparisons of horse SERCA to orthologs such as rabbit and human enzymes [36,63,64].

\section{Discussion}

The present study provides a comparative assessment of $\mathrm{Ca}^{2+}$ transport proteins from horse and rabbit muscle, thereby providing quantitative measurements of fundamental parameters of SR function at the molecular level. Our specific purpose was to analyze $\mathrm{SR} \mathrm{Ca}{ }^{2+}$ transport in horses, a species that has long been selected for speed by evolution and breeding. Here, we report the biochemical analysis of $\mathrm{Ca}^{2+}$ transport in horse SR vesicles, with comparison to widely used experimental models of SERCA and SR from rabbit muscle. The results provide new insights into $\mathrm{Ca}^{2+}$ transport regulations in horse muscle, including proposed mechanisms for high muscular performance.

\subsection{Analysis of SERCA $\mathrm{Ca}^{2+}$ Transport and ATPase Activities in SR Vesicles from Horse and Rabbit Muscle}

We compared SERCA activity from horse gluteus and rabbit skeletal muscles using a radiometric assay of $\mathrm{Ca}^{2+}$ transport. SERCA product-inhibition by accumulated luminal $\mathrm{Ca}^{2+}$ was relieved by an addition of the $\mathrm{Ca}^{2+}$-precipitating anion oxalate in the transport assay. We previously showed that the maximal rate of total $\mathrm{Ca}^{2+}$-activated ATPase activity of SERCA was lower in horse SR vesicles than in rabbit SR vesicles (measured per mg of SR protein), and that the specific activity (corrected for the relative content of SERCA per $\mathrm{mg}$ of SR protein) of horse SERCA was equal to or greater than that of rabbit SERCA [11]. Here, we report that the maximal rate of total ATP-dependent $\mathrm{Ca}^{2+}$ transport for horse SR vesicles is 2.3-fold greater than the $\mathrm{Ca}^{2+}$ transport $\mathrm{V}_{\max }$ measured for rabbit $\mathrm{SR}$ vesicles (mg horse SR protein/mg rabbit SR protein) (Figure 2), even though the SERCA content in SR vesicles is $\sim$ two-fold lower for the horse than the rabbit (Figure 1) [11].

The differences in the $\mathrm{V}_{\max }$ of the horse versus rabbit SERCA orthologs could potentially be attributed to the lack of SLN peptide in horse muscle $[10,11]$. Another possibility for increased transport is sequence variation in the horse versus rabbit SERCA proteins that affect the equilibrium distribution among biochemical intermediates, i.e., the activation energy for conformational transitions in steps along the enzymatic cycle [65]. For example, the single-residue variations $\mathrm{R} 164 \mathrm{H}$ and $\mathrm{R} 559 \mathrm{C}$ — each of which individually decrease the activity of bovine SERCA—are sufficient to induce congenital pseudomyotonia syndrome in cattle [66-68].

The horse and rabbit SERCA showed similar activation of ATP hydrolysis in vitro upon increasing the assay temperature from 20 to $45^{\circ} \mathrm{C}$ using $5{ }^{\circ} \mathrm{C}$ steps (Figure 3), indicating that the two orthologous $\mathrm{Ca}^{2+}$ pumps have a similar standard free energy of enzyme 
activation $\left(\mathrm{E}_{\mathrm{a}}\right)$, a key parameter that determines the rate of enzyme activity. Additionally, increasing the assay temperature from 45 to $50{ }^{\circ} \mathrm{C}$ inactivated both the horse and rabbit SERCA almost completely, suggesting that the SERCA Ca ${ }^{2+}$ pump from the two species share a similar thermostability, indicating similar energetics of unfolding for key structural element(s) involved in enzyme catalysis. The lack of difference in the temperature dependence of $\mathrm{Ca}^{2+}$-ATPase activity by horse and rabbit SERCA (Figure 3) does not support the activity difference due to phospholipids: either directly through altered lipid composition and protein interaction, or indirectly through membrane fluidity and bilayer phase modulation. An additional biochemical assay of the SERCA structure and function used the conformation-specific ProtK cleavage assay (Figure 4), which provided information to help interpret the results from the standard $\mathrm{Ca}^{2+}$ transport (Figure 2) and the $\mathrm{Ca}^{2+}$-ATPase [11] assays. The ProtK assay revealed a similar pattern of protein cleavage for the horse and rabbit SERCA in $\mathrm{Ca}^{2+}$-bound and $\mathrm{Ca}^{2+}$-free biochemical states. Thus, this result indicates a similar residue accessibility and structural dynamics on the stalks segments of the actuator domain for the two SERCA orthologs in each specific ligand-stabilized biochemical intermediate (e.g., residue L119 in E2•TG or residue T242 in E1•2Ca ${ }^{2+}$ ). Although neither of these two biochemical assays provided information on molecular mechanism(s) that produce robust $\mathrm{Ca}^{2+}$ transport by horse SR, both assays demonstrated the functional and structural similarities of SERCA orthologs from horse gluteus and rabbit muscles.

\subsection{The Relative Ratio of $\mathrm{Ca}^{2+}$ Transport to ATP Hydrolysis Is Greater for Horse SR Vesicles Than} Rabbit SR Vesicles

SLN decreases the energetic efficiency of SERCA activity by partially uncoupling $\mathrm{Ca}^{2+}$ transport from ATP hydrolysis, i.e., by decreasing the $\mathrm{Ca}^{2+}$ / ATP coupling ratio below the maximum ratio of $2 \mathrm{Ca}^{2+}$ ions transported per ATP molecule hydrolyzed $[18,20-23,26]$. Table 1 reports the $\mathrm{Ca}^{2+}$ transport and ATP hydrolysis activities of horse and rabbit SR vesicles. The following two separate and distinct experimental procedures were utilized to determine each of these activities: (i) an oxalate-facilitated ${ }^{45} \mathrm{Ca}^{2+}$ transport assay and (ii) an ionophore-facilitated ATPase assay. Thus, due to the different experiment conditions designed to relieve product inhibition for steady-state biochemical assays (e.g., precipitation of ${ }^{45} \mathrm{Ca}^{2+}$-oxalate deposits within SR vesicles vs. an ionophore-mediated release of $\mathrm{Ca}^{2+}$ from SR vesicles), calculating the absolute coupling ratio of SERCA was not feasible. However, the relative ratio of the $\mathrm{Ca}^{2+}$ uptake per ATP hydrolysis could be calculated as an activity/activity ratio (IU/IU) (see Table 1, Column 4). With this relative ratio of SERCA functions (i.e., a pseudo-coupling ratio), the horse $S R$ vesicles showed a $\sim 1 / 1$ proportion of $\mathrm{Ca}^{2+}$ transport to ATPase activities, as determined by four reports measuring both activities (Table 1) $[11,56,58,59]$. This relative ratio of $\sim 1 / 1$ transport/ATPase in horse SR vesicles was observed using distinct protocols for the isolation of SR vesicles from horse skeletal muscle, even though the horse SR preps showed a range of 5-25-fold difference in the measured activities (Table 1). In comparison, the SR vesicles from rabbit skeletal muscle (which expresses near equimolar levels of SERCA and SLN) showed a relative ratio of $\sim 0.3$ transport/ATPase, using the two separate assays for each activity, i.e., determining the pseudo-coupling ratio (Table 1). We propose that SERCA in horse SR vesicles shows a greater apparent $\mathrm{Ca}^{2+} /$ ATP coupling ratio due to minimal SLN content in the SR membrane [10,11] and an abundant CASQ in the SR lumen (Figure 1) [11].

\subsection{Proposed Physiological Effects of Minimal Expression of SLN and Abundant Expression of CASQ on Horse Muscular Performance}

We hypothesize that the low SLN/SERCA protein ratio in horse SR vesicles enhances the rate of $\mathrm{SR} \mathrm{Ca}{ }^{2+}$ uptake and the loading level of $\mathrm{SR} \mathrm{Ca}^{2+}$ stores. Horse SR shows $\sim$ two-fold greater rate of $\mathrm{Ca}^{2+}$ transport than rabbit SR (Figure 2), even though horse SR expresses a $\sim$ two-fold lower SERCA content than rabbit SR (Figure 1) [11]. These results from horse SR are consistent with those from transgenic mouse models in which (i) the knock-out of SLN protein expression in slow-twitch soleus muscle increases the rate of $\mathrm{Ca}^{2+}$ transport by SERCA, and (ii) the over-expression of SLN protein in cardiac and skeletal 
muscle decreases the rate of $\mathrm{Ca}^{2+}$ transport by SERCA $[27,28,69]$. For horse myocytes, the increased rate of $\mathrm{Ca}^{2+}$ transport by SERCA and the increased expression level of CASQ suggests that horse SR accumulates, stores, and releases an increased level of total $\mathrm{Ca}^{2+}$, thereby producing an ionotropic-like enhancement of muscle contractility [70].

CASQ is the primary $\mathrm{Ca}^{2+}$ storage protein in SR, and CASQ is tightly linked to the regulation of $\mathrm{Ca}^{2+}$ cycling in muscle. Since $\mathrm{SR} \mathrm{Ca}^{2+}$ release is sensitized by luminal $\mathrm{Ca}^{2+}$, an increase in luminal $\mathrm{Ca}^{2+}$ stores and an associated $\mathrm{RYR} 1 \mathrm{Ca}^{2+}$ release could result in a more rapid and more powerful muscle contraction, i.e., producing a positive inotropic effect in vivo. The correlation of a higher rate of SERCA transport in SR vesicles with an increased rate of clearance of cytosolic $\mathrm{Ca}^{2+}$ transient suggests that horse myocytes exhibit a positive lusitropic effect (Figure 5).

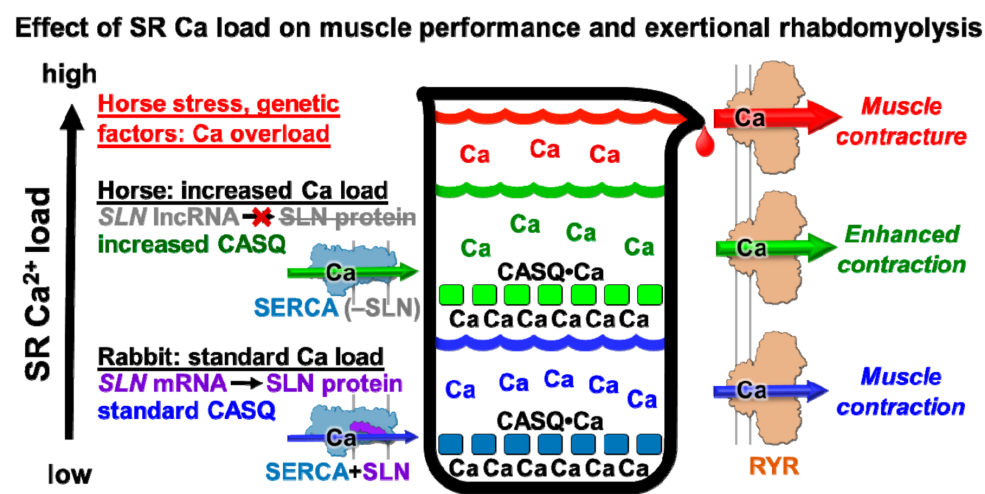

Figure 5. Proposed model for the roles of SR calcium regulation in horse muscle performance and exertional rhabdomyolysis. This schematic diagram illustrates the hypothesis that luminal $\mathrm{Ca}^{2+}$ stores and $\mathrm{Ca}^{2+}$ cycling in horse myofibers are enhanced by a relatively low ratio of SLN/SERCA and a relatively high ratio of CASQ/SERCA. We propose that high luminal $\mathrm{Ca}^{2+}$ promotes a store overloadinduced $\mathrm{Ca}^{2+}$ release (SOICR) through the RYR Ca ${ }^{2+}$ channel [30,32], which, combined with stressinduced RYR Ca ${ }^{2+}$ leak [71,72], increase the incidence of contracture events in horse muscle [6,7,73,74]. It is possible that the subsequent $\mathrm{Ca}^{2+}$-induced activation of proteases, lipases, oxidative stress, and cellular remodeling contributes to the etiology of equine exertional rhabdomyolysis [8].

Horse breeds have been bred selectively to further enhance their speed and with that has come an incidence of exertional rhabdomyolysis of 3-7\% $[4,75]$. Elevated cytosolic $\mathrm{Ca}^{2+}$ has been detected in (a) primary myocytes isolated from horse muscle during an episode of acute exertional rhabdomyolysis [76] and (b) cultured myocytes differentiated from muscle myoblasts obtained from horses susceptible to recurrent exertional rhabdomyolysis [74]. The lack of a protein expression of SERCA regulatory peptides in horse muscle may be a molecular mechanism to produce strong acceleration and rapid muscular relaxation, thereby giving horses an advantage in escaping predators. While slightly elevated cytosolic $\mathrm{Ca}^{2+}$ may provide an advantage that enhances muscle power output, excessively elevated cytosolic $\mathrm{Ca}^{2+}$ may become a disadvantage that decreases contractility, such as through an SR store overload-induced $\mathrm{Ca}^{2+}$ release (SOICR) [32]. We suggest that a heritable crossover between these two contractile conditions may occur following genetic pressure such as performance-based breeding (Figure 5).

We propose that the low SLN/SERCA protein ratio in horse SR vesicles enhances the rate of SR $\mathrm{Ca}^{2+}$ reuptake and the loading level of SR $\mathrm{Ca}^{2+}$ stores, thereby enabling a more rapid and more powerful contraction of horse gluteal muscle in vivo. An increase in the intrinsic rate of $\mathrm{Ca}^{2+}$ transport by horse SERCA (i.e., a possible lack of SLN uncoupling and/or an enhanced $V_{\max }$ ), coupled with a robust level of CASQ expression, may also serve as molecular mechanisms that potentiate SR contributions to functional contractility in horse muscle (Figure 5). 


\subsection{Proposed Role of SLN Expression in Horse Exertional Rhabdomyolysis and Relationship to Human Muscular Dystrophies}

With the natural selection of horses as fast-moving prey animals, why would they evolve to have a unique SLN amino acid sequence and lack of expression that are not present in closely related ungulates such as rhinoceros? One possible advantage for the lack of a SERCA regulatory peptide inhibitor includes a genetic improvement that generates an increased luminal $\mathrm{Ca}^{2+}$ load to provide a greater ability to escape predators due to stronger acceleration and stronger contraction. After breeding over millennia, could enhanced $\mathrm{Ca}^{2+}$ cycling and contractile abilities have been selected to the extreme in some breeds, with SLN RNA upregulated and SLN protein downregulated? Thoroughbred horses with recurrent exertional rhabdomyolysis (RER) have $50 \%$ faster relaxation times than horses that are not predisposed to recurrent exertional rhabdomyolysis [73]. Furthermore, horses with recurrent exertional rhabdomyolysis have faster racing speeds than horses that are not predisposed to exertional rhabdomyolysis [3]. Thus, two parameters of horse muscular performance are associated with horse susceptibility to RER.

In human muscular dystrophies, the effect of modulating the SLN expression level and the inhibitory function is unknown. In compelling mouse and canine models, enhancing SLN protein expression has been proposed as an effective therapy, as reported by Babu et al. [77]. Indeed, SLN gene expression and protein levels are increased many-fold in standard mouse models of Duchenne muscular dystrophy, e.g., $m d x$ and $m d x / u t r-d k o$ [28]. However, decreasing the SLN expression in mouse models is reported to have beneficial or deleterious effects, depending on the genetic model and etiology studied [77-79]. To help delineate these disparate effects, additional correlations should be determined between $\mathrm{Ca}^{2+}$ transport regulation and muscular performance in animal models and human disease, which could then provide insights on the utilization of species-dependent mechanisms for contractile and therapeutic control.

\section{Conclusions}

Our integrative cellular, transcriptional, and biochemical methodologies $[9-11,80,81]$ provide novel information on SERCA activity in horse SR, which is a unique physiological system with high-capacity $\mathrm{Ca}^{2+}$ transport. The results reported here contribute to the understanding of $\mathrm{Ca}^{2+}$ cycling in myocytes, with relevance to muscular performance, adaptability, and disease. The results shown here provide a foundation to further dissect the mechanistic roles of SERCA, CASQ, and SLN in horse muscle contractility, including correlations with gene and protein expression levels. We propose that analyses of horse $\mathrm{Ca}^{2+}$ transport will enhance the basic understanding and therapeutic utilization of $\mathrm{Ca}^{2+}$ control in muscle contractility.

Supplementary Materials: The following are available online at https://www.mdpi.com/article/ 10.3390/vetsci8120289/s1, Figure S1: SLN Western blot of SR vesicles using a novel, custom-ordered anti-horse-SLN polyclonal antibodies pAb 3378, Table S1: Horse muscle tissue samples, Table S2: Densitometry data for Coomassie gel.

Author Contributions: Conceptualization, J.M.A., D.D.T. and S.J.V.; Data curation, J.M.A. and S.J.V.; Data analysis, J.M.A., B.S. and S.J.V.; Funding acquisition, J.M.A., Z.C., B.S., R.L.C., D.D.T. and S.J.V.; Investigation, J.M.A., Z.C., S.F.C., B.S. and S.J.V.; Methodology, J.M.A. and S.J.V.; Project administration, J.M.A., D.D.T. and S.J.V.; Resources, J.M.A., Z.C., D.D.T. and S.J.V.; Supervision, J.M.A., D.D.T. and S.J.V.; Validation, J.M.A. and S.J.V.; Visualization, J.M.A., S.F.C., B.S. and S.J.V.; Writing—original draft, J.M.A., B.S. and S.J.V.; Writing—review and editing, J.M.A., B.S., R.L.C., D.D.T. and S.J.V. All authors have read and agreed to the published version of the manuscript.

Funding: This study was supported in part by a Morris Animal Foundation grant to S.J.V, J.M.A., and D.D.T. (grant number D16EQ-004). Morris Animal Foundation is the global leader in supporting science that advances animal health. This study was supported in part by National Institutes of Health grants to D.D.T. (grant numbers GM027906 and AG026160) and to D.D.T. and R.L.C. (HL139065). The content is solely the responsibility of the authors and does not necessarily represent 
the official views of the National Institutes of Health. This study was supported in part by an American Heart Association grant to Z.C. (grant number 18TPA34170284/Chen, Zhenhui/2018). The funding agencies had no role in study design, data collection, data analysis, manuscript preparation, or decision to publish.

Institutional Review Board Statement: The study was conducted according to the guidelines of the Declaration of Helsinki, and approved by the Institutional Animal Care and Use Committee (IACUC) at the University of Minnesota, with IACUC protocol \# 1511-33199A (2015-11) for horses and IACUC protocol \# 1611-34327A (2017-04) for rabbits.

Informed Consent Statement: Not applicable.

Data Availability Statement: Data supporting the findings of this study are available within the article and/or its Supplementary Material. Full raw data sets are available from the corresponding authors, upon reasonable request.

Acknowledgments: We thank Robyn T. Rebbeck for help with statistical analysis and critical reading of the manuscript; Christine B. Karim for running the Western blot; Jonathan S. Marchant for access to laboratory equipment; Seth L. Robia and L. Michel Espinoza-Fonseca for insightful discussion; Samantha L. Yuen and Ty D. Gaedtke for technical support; and Octavian Cornea, Sarah Blakely Anderson, and Destiny Ziebol for administrative support. Spectrophotometric assays were performed in the Biophysical Technology Center, University of Minnesota Department of Biochemistry, Molecular Biology, and Biophysics.

Conflicts of Interest: The authors declare that they have no conflicts of interest with the contents of this article. S.J.V. is part-owner of the license for genetic testing of equine type 1 polysaccharide storage myopathy, glycogen branching enzyme deficiency, and myosin 1 myopathy, receiving sales income from their diagnostic use. S.J.V. also receives royalties from the sale of Re-Leve equine feed. The financial and business interests of S.J.V. have been reviewed and managed by Michigan State University in accordance with MSU conflict of interest policies. D.D.T. and R.L.C. hold equity in and serve as executive officers for Photonic Pharma LLC. The financial and business interests of D.D.T. and R.L.C. have been reviewed and managed by the University of Minnesota in accordance with UMN conflict of interest policies. Photonic Pharma LLC had no role in this study.Acronyms and AbbreviationsCASQ, calsequestrin; IU, international unit of enzyme activity, defined as the production of $1 \mu \mathrm{mol}$ product per milligram protein per minute; $\mathrm{K}_{\mathrm{ATP}}$, ATP dissociation constant of SERCA; $\mathrm{K}_{\mathrm{Ca}}$, apparent $\mathrm{Ca}^{2+}$ dissociation constant of SERCA, defined as the $\mathrm{Ca}^{2+}$ concentration required for half-maximal activation of activity; lncRNA, long non-coding RNA; MRLN, myoregulin; PLN, phospholamban; ProtK, proteinase K; RER, recurrent exertional rhabdomyolysis; RNA-seq, whole transcriptome shotgun sequencing; RYR, ryanodine receptor $\mathrm{Ca}^{2+}$ release channel; SERCA, sarco/endoplasmic reticulum Ca2+-transporting ATPase; SLN, sarcolipin; SR, sarcoplasmic reticulum; $\mathrm{V}_{\max }$, maximal enzyme velocity of SERCA, defined as the $\mathrm{Ca}^{2+}$-activated ATPase activity or $\mathrm{Ca}^{2+}$ transport activity at saturating concentrations of ionized $\mathrm{Ca}^{2+}(\sim 1-10 \mu \mathrm{M})$ and $\operatorname{MgATP}(\sim 3-10 \mathrm{mM})$.

\section{References}

1. Valberg, S.J. Muscle conditions affecting sport horses. Vet. Clin. N. Am. Equine Pract. 2018, 34, 253-276. [CrossRef] [PubMed]

2. Mickelson, J.R.; Valberg, S.J. The genetics of skeletal muscle disorders in horses. Annu. Rev. Anim. Biosci. 2015, 3, 197-217. [CrossRef] [PubMed]

3. Isgren, C.M.; Upjohn, M.M.; Fernandez-Fuente, M.; Massey, C.; Pollott, G.; Verheyen, K.L.; Piercy, R.J. Epidemiology of exertional rhabdomyolysis susceptibility in standardbred horses reveals associated risk factors and underlying enhanced performance. PLoS ONE 2010, 5, e11594. [CrossRef] [PubMed]

4. MacLeay, J.M.; Sorum, S.A.; Valberg, S.J.; Marsh, W.E.; Sorum, M.D. Epidemiologic analysis of factors influencing exertional rhabdomyolysis in Thoroughbreds. Am. J. Vet. Res. 1999, 60, 1562-1566.

5. Ward, T.L.; Valberg, S.J.; Gallant, E.M.; Mickelson, J.R. Calcium regulation by skeletal muscle membranes of horses with recurrent exertional rhabdomyolysis. Am. J. Vet. Res. 2000, 61, 242-247. [CrossRef]

6. Mlekoday, J.A.; Mickelson, J.R.; Valberg, S.J.; Horton, J.H.; Gallant, E.M.; Thompson, L.V. Calcium sensitivity of force production and myofibrillar ATPase activity in muscles from Thoroughbreds with recurrent exertional rhabdomyolysis. Am. J. Vet. Res. 2001, 62, 1647-1652. [CrossRef]

7. Lentz, L.R.; Valberg, S.J.; Mickelson, J.R.; Gallant, E.M. In vitro contractile responses and contracture testing of skeletal muscle from Quarter Horses with exertional rhabdomyolysis. Am. J. Vet. Res. 1999, 60, 684-688. 
8. Aldrich, K.; Velez-Irizarry, D.; Fenger, C.; Schott, M.; Valberg, S.J. Pathways of calcium regulation, electron transport, and mitochondrial protein translation are molecular signatures of susceptibility to recurrent exertional rhabdomyolysis in Thoroughbred racehorses. PLOS ONE 2021, 16, e0244556. [CrossRef]

9. Valberg, S.J.; Soave, K.; Williams, Z.J.; Perumbakkam, S.; Schott, M.; Finno, C.J.; Petersen, J.L.; Fenger, C.; Autry, J.M.; Thomas, D.D. Coding sequences of sarcoplasmic reticulum calcium ATPase regulatory peptides and expression of calcium regulatory genes in recurrent exertional rhabdomyolysis. J. Vet. Intern. Med. 2019, 33, 933-941. [CrossRef]

10. Autry, J.M.; Karim, C.B.; Perumbakkam, S.; Finno, C.J.; McKenzie, E.C.; Thomas, D.D.; Valberg, S.J. Sarcolipin Exhibits Abundant RNA Transcription and Minimal Protein Expression in Horse Gluteal Muscle. Vet. Sci. 2020, 7, 178. [CrossRef]

11. Autry, J.M.; Karim, C.B.; Cocco, M.; Carlson, S.F.; Thomas, D.D.; Valberg, S.J. Purification of sarcoplasmic reticulum vesicles from horse gluteal muscle. Anal. Biochem. 2020, 610, 113965. [CrossRef]

12. Montigny, C.; Decottignies, P.; Le Marechal, P.; Capy, P.; Bublitz, M.; Olesen, C.; Møller, J.V.; Nissen, P.; le Maire, M. Spalmitoylation and s-oleoylation of rabbit and pig sarcolipin. J. Biol. Chem. 2014, 289, 33850-33861. [CrossRef]

13. Vangheluwe, P.; Schuermans, M.; Zador, E.; Waelkens, E.; Raeymaekers, L.; Wuytack, F. Sarcolipin and phospholamban mRNA and protein expression in cardiac and skeletal muscle of different species. Biochem. J. 2005, 389, 151-159. [CrossRef]

14. Fajardo, V.A.; Bombardier, E.; Vigna, C.; Devji, T.; Bloemberg, D.; Gamu, D.; Gramolini, A.O.; Quadrilatero, J.; Tupling, A.R. Co-expression of SERCA isoforms, phospholamban and sarcolipin in human skeletal muscle fibers. PLoS ONE 2013, 8, e84304. [CrossRef]

15. Babu, G.J.; Bhupathy, P.; Carnes, C.A.; Billman, G.E.; Periasamy, M. Differential expression of sarcolipin protein during muscle development and cardiac pathophysiology. J. Mol. Cell. Cardiol. 2007, 43, 215-222. [CrossRef]

16. Qaisar, R.; Bhaskaran, S.; Premkumar, P.; Ranjit, R.; Natarajan, K.S.; Ahn, B.; Riddle, K.; Claflin, D.R.; Richardson, A.; Brooks, S.V.; et al. Oxidative stress-induced dysregulation of excitation-contraction coupling contributes to muscle weakness. J. Cachexia Sarcopenia Muscle 2018, 9, 1003-1017. [CrossRef]

17. Odermatt, A.; Becker, S.; Khanna, V.K.; Kurzydlowski, K.; Leisner, E.; Pette, D.; MacLennan, D.H. Sarcolipin regulates the activity of SERCA1, the fast-twitch skeletal muscle sarcoplasmic reticulum $\mathrm{Ca}^{2+}$-ATPase. J. Biol. Chem. 1998, 273, 12360-12369. [CrossRef]

18. Smith, W.S.; Broadbridge, R.; East, J.M.; Lee, A.G. Sarcolipin uncouples hydrolysis of ATP from accumulation of Ca ${ }^{2+}$ by the $\mathrm{Ca}^{2+}$-ATPase of skeletal-muscle sarcoplasmic reticulum. Biochem. J. 2002, 361, 277-286. [CrossRef]

19. Gorski, P.A.; Glaves, J.P.; Vangheluwe, P.; Young, H.S. Sarco(endo)plasmic reticulum calcium ATPase (SERCA) inhibition by sarcolipin is encoded in its luminal tail. J. Biol. Chem. 2013, 288, 8456-8467. [CrossRef]

20. Sahoo, S.K.; Shaikh, S.A.; Sopariwala, D.H.; Bal, N.C.; Bruhn, D.S.; Kopec, W.; Khandelia, H.; Periasamy, M. The N terminus of sarcolipin plays an important role in uncoupling sarco-endoplasmic reticulum Ca2+-ATPase (SERCA) ATP hydrolysis from Ca2+ transport. J. Biol. Chem. 2015, 290, 14057-14067. [CrossRef]

21. Autry, J.M.; Thomas, D.D.; Espinoza-Fonseca, L.M. Sarcolipin Promotes Uncoupling of the SERCA Ca(2+) Pump by Inducing a Structural Rearrangement in the Energy-Transduction Domain. Biochemistry 2016, 55, 6083-6086. [CrossRef] [PubMed]

22. Barbot, T.; Beswick, V.; Montigny, C.; Quiniou, E.; Jamin, N.; Mouawad, L. Deciphering the Mechanism of Inhibition of SERCA1a by Sarcolipin Using Molecular Simulations. Front. Mol. Biosci. 2020, 7, 606254. [CrossRef] [PubMed]

23. Montigny, C.; Huang, D.L.; Beswick, V.; Barbot, T.; Jaxel, C.; le Maire, M.; Zheng, J.S.; Jamin, N. Sarcolipin alters SERCA1a interdomain communication by impairing binding of both calcium and ATP. Sci. Rep. 2021, 11, 1641. [CrossRef] [PubMed]

24. Gramolini, A.O.; Trivieri, M.G.; Oudit, G.Y.; Kislinger, T.; Li, W.; Patel, M.M.; Emili, A.; Kranias, E.G.; Backx, P.H.; Maclennan, D.H. Cardiac-specific overexpression of sarcolipin in phospholamban null mice impairs myocyte function that is restored by phosphorylation. Proc. Natl. Acad. Sci. USA 2006, 103, 2446-2451. [CrossRef]

25. Bhupathy, P.; Babu, G.J.; Ito, M.; Periasamy, M. Threonine-5 at the N-terminus can modulate sarcolipin function in cardiac myocytes. J. Mol. Cell. Cardiol. 2009, 47, 723-729. [CrossRef]

26. Barbot, T.; Montigny, C.; Decottignies, P.; le Maire, M.; Jaxel, C.; Jamin, N.; Beswick, V. Functional and structural insights into sarcolipin, a regulator of the sarco-endoplasmic reticulum $\mathrm{Ca}^{2+}$-ATPases. In Regulation of $\mathrm{Ca}^{2+}$-ATPases, V-ATPases and F-ATPases, 14th ed.; Chakraborti, S., Dhalla, N.S., Eds.; Springer International Publishing: Basel, Switzerland, 2016; pp. $153-186$.

27. Tupling, A.R.; Bombardier, E.; Gupta, S.C.; Hussain, D.; Vigna, C.; Bloemberg, D.; Quadrilatero, J.; Trivieri, M.G.; Babu, G.J.; Backx, P.H.; et al. Enhanced $\mathrm{Ca}^{2+}$ transport and muscle relaxation in skeletal muscle from sarcolipin-null mice. Am. J. Physiol.-Cell Physiol. 2011, 301, C841-C849. [CrossRef]

28. Shanmugam, M.; Molina, C.E.; Gao, S.; Severac-Bastide, R.; Fischmeister, R.; Babu, G.J. Decreased sarcolipin protein expression and enhanced sarco(endo)plasmic reticulum Ca2+ uptake in human atrial fibrillation. Biochem. Biophys. Res. Commun. 2011, 410, 97-101. [CrossRef]

29. Molina, C.E.; Abu-Taha, I.H.; Wang, Q.; Rosello-Diez, E.; Kamler, M.; Nattel, S.; Ravens, U.; Wehrens, X.H.T.; Hove-Madsen, L.; Heijman, J.; et al. Profibrotic, electrical, and calcium-handling remodeling of the atria in heart failure patients with and without atrial fibrillation. Front. Physiol. 2018, 9, 1383. [CrossRef]

30. Wakizaka, M.; Eshima, H.; Tanaka, Y.; Shirakawa, H.; Poole, D.C.; Kano, Y. In vivo Ca $\left({ }^{2+}\right)$ dynamics induced by Ca $\left({ }^{2+}\right)$ injection in individual rat skeletal muscle fibers. Physiol. Rep. 2017, 5, e13180. [CrossRef]

31. Murayama, T.; Kurebayashi, N.; Ogawa, H.; Yamazawa, T.; Oyamada, H.; Suzuki, J.; Kanemaru, K.; Oguchi, K.; Iino, M.; Sakurai, T. Genotype-phenotype correlations of malignant hyperthermia and central core disease mutations in the central region of the RYR1 channel. Hum. Mutat. 2016, 37, 1231-1241. [CrossRef] 
32. Kong, H.; Wang, R.; Chen, W.; Zhang, L.; Chen, K.; Shimoni, Y.; Duff, H.J.; Chen, S.R. Skeletal and cardiac ryanodine receptors exhibit different responses to Ca2+ overload and luminal $\mathrm{Ca}^{2+}$. Biophys. J. 2007, 92, 2757-2770. [CrossRef]

33. Kim, E.; Youn, B.; Kemper, L.; Campbell, C.; Milting, H.; Varsanyi, M.; Kang, C. Characterization of human cardiac calsequestrin and its deleterious mutants. J. Mol. Biol. 2007, 373, 1047-1057. [CrossRef]

34. Sanchez, E.J.; Lewis, K.M.; Munske, G.R.; Nissen, M.S.; Kang, C. Glycosylation of skeletal calsequestrin: Implications for its function. J. Biol. Chem. 2012, 287, 3042-3050. [CrossRef]

35. McDonald, A.G.; Boyce, S.; Tipton, K.F. ExplorEnz: The primary source of the IUBMB enzyme list. Nucleic Acids Res. 2009, 37, D593-D597. [CrossRef]

36. Ikemoto, N.; Sreter, F.A.; Gergely, J. Structural features of the surface of the vesicles of FSR-lack of functional role in Ca ${ }^{2+}$ uptake and ATPase activity. Arch. Biochem. Biophys. 1971, 147, 571-582. [CrossRef]

37. Autry, J.M.; Jones, L.R. Functional co-expression of the canine cardiac $\mathrm{Ca}^{2+}$ pump and phospholamban in Spodoptera frugiperda (Sf21) cells reveals new insights on ATPase regulation. J. Biol. Chem. 1997, 272, 15872-15880. [CrossRef]

38. Jones, L.R.; Besch, H.R., Jr.; Watanabe, A.M. Regulation of the calcium pump of cardiac sarcoplasmic reticulum. Interactive roles of potassium and ATP on the phosphoprotein intermediate of the $\left(\mathrm{K}^{+}, \mathrm{Ca}^{2+}\right)$-ATPase. J. Biol. Chem. 1978, 253, 1643-1653. [CrossRef]

39. Danko, S.; Yamasaki, K.; Daiho, T.; Suzuki, H. Membrane perturbation of ADP-insensitive phosphoenzyme of Ca( $\left.{ }^{2+}\right)$-ATPase modifies gathering of transmembrane helix M2 with cytoplasmic domains and luminal gating. Sci. Rep. 2017, 7, 41172. [CrossRef]

40. Møller, J.V.; Lenoir, G.; Marchand, C.; Montigny, C.; le Maire, M.; Toyoshima, C.; Juul, B.S.; Champeil, P. Calcium transport by sarcoplasmic reticulum $\mathrm{Ca}\left({ }^{2+}\right)$-ATPase. Role of the A domain and its C-terminal link with the transmembrane region. J. Biol. Chem. 2002, 277, 38647-38659. [CrossRef]

41. Autry, J.M.; Rubin, J.E.; Svensson, B.; Li, J.; Thomas, D.D. Nucleotide activation of the Ca-ATPase. J. Biol. Chem. 2012, 287, 39070-39082. [CrossRef]

42. Shutova, A.N.; Storey, K.B.; Lopina, O.D.; Rubtsov, A.M. Comparative characteristics of sarcoplasmic reticulum preparations from skeletal muscles of the ground squirrel Spermophilus undulatus, rats, and rabbits. Biochem. C/C Biokhimiia 1999, 64, $1250-1257$.

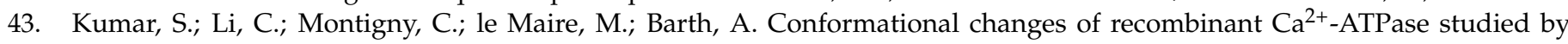
reaction-induced infrared difference spectroscopy. FEBS J. 2013, 280, 5398-5407. [CrossRef] [PubMed]

44. Butler, J.; Smyth, N.; Broadbridge, R.; Council, C.E.; Lee, A.G.; Stocker, C.J.; Hislop, D.C.; Arch, J.R.; Cawthorne, M.A.; Malcolm East, J. The effects of sarcolipin over-expression in mouse skeletal muscle on metabolic activity. Arch. Biochem. Biophys. 2015, 569, 26-31. [CrossRef] [PubMed]

45. Murphy, R.M.; Larkins, N.T.; Mollica, J.P.; Beard, N.A.; Lamb, G.D. Calsequestrin content and SERCA determine normal and maximal $\mathrm{Ca}^{2+}$ storage levels in sarcoplasmic reticulum of fast- and slow-twitch fibres of rat. J. Physiol. 2009, 587, 443-460. [CrossRef]

46. Cala, S.E.; Jones, L.R. Rapid purification of calsequestrin from cardiac and skeletal muscle sarcoplasmic reticulum vesicles by $\mathrm{Ca}^{2+}$-dependent elution from phenyl-sepharose. J. Biol. Chem. 1983, 258, 11932-11936. [CrossRef]

47. Kozlowski, L.P. IPC-Isoelectric point calculator. Biol. Direct 2016, 11, 55. [CrossRef]

48. Jones, L.R.; Besch, H.R., Jr.; Watanabe, A.M. Monovalent cation stimulation of $\mathrm{Ca}^{2+}$ uptake by cardiac membrane vesicles. J. Biol. Chem. 1977, 252, 3315-3323. [CrossRef]

49. Jones, L.R.; Besch, H.R., Jr.; Fleming, J.W.; McConnaughey, M.M.; Watanabe, A.M. Separation of vesicles of cardiac sarcolemma from vesicles of cardiac sarcoplasmic reticulum. Comparative biochemical analysis of component activities. J. Biol. Chem. 1979, 254, 530-539. [CrossRef]

50. Jones, L.R.; Cala, S.E. Biochemical evidence for functional heterogeneity of cardiac sarcoplasmic reticulum vesicles. J. Biol. Chem. 1981, 256, 11809-11818. [CrossRef]

51. Borchman, D.; Simon, R.; Bicknell-Brown, E. Variation in the lipid composition of rabbit muscle sarcoplasmic reticulum membrane with muscle type. J. Biol. Chem. 1982, 257, 14136-14139. [CrossRef]

52. Smith, G.L.; Eisner, D.A. Calcium Buffering in the Heart in Health and Disease. Circulation 2019, 139, 2358-2371. [CrossRef]

53. Inesi, G.; Tadini-Buoninsegni, F. $\mathrm{Ca}\left({ }^{2+}\right)^{/} \mathrm{H}\left({ }^{+}\right)$exchange, lumenal $\mathrm{Ca}\left({ }^{2+}\right)$ release and $\mathrm{Ca}\left({ }^{2+}\right) / \mathrm{ATP}$ coupling ratios in the sarcoplasmic reticulum ATPase. J. Cell Commun. Signal. 2014, 8, 5-11. [CrossRef]

54. MacLennan, D.H.; Holland, P.C. Calcium transport in sarcoplasmic reticulum. Annu. Rev. Biophys. Bioeng. 1975, 4, 377-404. [CrossRef]

55. Sagara, Y.; Inesi, G. Inhibition of the sarcoplasmic reticulum Ca2+ transport ATPase by thapsigargin at subnanomolar concentrations. J. Biol. Chem. 1991, 266, 13503-13506. [CrossRef]

56. Byrd, S.K.; McCutcheon, L.J.; Hodgson, D.R.; Gollnick, P.D. Altered sarcoplasmic reticulum function after high-intensity exercise. J. Appl. Physiol. 1989, 67, 2072-2077. [CrossRef]

57. Beech, J.; Lindborg, S.; Fletcher, J.E.; Lizzo, F.; Tripolitis, L.; Braund, K. Caffeine contractures, twitch characteristics and the threshold for $\mathrm{Ca}\left({ }^{2+}\right)$-induced $\mathrm{Ca}^{2+}$ release in skeletal muscle from horses with chronic intermittent rhabdomyolysis. Res. Vet. Sci. 1993, 54, 110-117. [CrossRef]

58. Wilson, J.A.; Kronfeld, D.S.; Gay, L.; Wilson, T.M. Isolating equine sarcoplasmic reticulum: Its function during high intensity repeated springs. Equine Vet. J. 1995, 27 (Suppl. 18), 252-255. [CrossRef] 
59. Wilson, J.A.; Kronfeld, D.S.; Gay, L.S.; Williams, J.H.; Wilson, T.M.; Lindinger, M.I. Sarcoplasmic reticulum responses to repeated sprints are affected by conditioning of horses. J. Anim. Sci. 1998, 76, 3065-3071. [CrossRef]

60. Marlin, D.J.; Scott, C.M.; Roberts, C.A.; Casas, I.; Holah, G.; Schroter, R.C. Post exercise changes in compartmental body temperature accompanying intermittent cold water cooling in the hyperthermic horse. Equine Vet. J. 1998, 30, 28-34. [CrossRef]

61. Ramirez-Soto, I.; Rodriguez, E.; Alvarez, R.; Quiroz, E.; Ortega, A. Intracellular effect of beta3-adrenoceptor agonist Carazolol on skeletal muscle, a direct interaction with SERCA. Cell Calcium 2019, 79, 20-26. [CrossRef]

62. Toyoshima, C.; Nomura, H. Structural changes in the calcium pump accompanying the dissociation of calcium. Nature 2002, 418, 605-611. [CrossRef] [PubMed]

63. Møller, J.V.; Olesen, C.; Winther, A.M.; Nissen, P. The sarcoplasmic Ca ${ }^{2+}$-ATPase: Design of a perfect chemi-osmotic pump. Q Rev. Biophys. 2010, 43, 501-566. [CrossRef] [PubMed]

64. Tsunekawa, N.; Ogawa, H.; Tsueda, J.; Akiba, T.; Toyoshima, C. Mechanism of the E2 to E1 transition in Ca $\left({ }^{2+}\right)$ pump revealed by crystal structures of gating residue mutants. Proc. Natl. Acad. Sci. USA 2018, 115, 12722-12727. [CrossRef] [PubMed]

65. Autry, J.M.; Svensson, B.; Espinoza-Fonseca, L.M.; Valberg, S.J.; Thomas, D.D. Homology structural modeling and comparative sequence analysis of the horse SERCA calcium pump and sarcolipin inhibitory subunit. 2021. submitted.

66. Drogemuller, C.; Drogemuller, M.; Leeb, T.; Mascarello, F.; Testoni, S.; Rossi, M.; Gentile, A.; Damiani, E.; Sacchetto, R. Identification of a missense mutation in the bovine ATP2A1 gene in congenital pseudomyotonia of Chianina cattle: An animal model of human Brody disease. Genomics 2008, 92, 474-477. [CrossRef]

67. Sacchetto, R.; Testoni, S.; Gentile, A.; Damiani, E.; Rossi, M.; Liguori, R.; Drogemuller, C.; Mascarello, F. A defective SERCA1 protein is responsible for congenital pseudomyotonia in Chianina cattle. Am. J. Pathol. 2009, 174, 565-573. [CrossRef]

68. Grunberg, W.; Sacchetto, R.; Wijnberg, I.; Neijenhuis, K.; Mascarello, F.; Damiani, E.; Drogemuller, C. Pseudomyotonia, a muscle function disorder associated with an inherited ATP2A1 (SERCA1) defect in a Dutch Improved Red and White cross-breed calf. Neuromuscul. Disord. 2010, 20, 467-470. [CrossRef]

69. Fajardo, V.A.; Rietze, B.A.; Chambers, P.J.; Bellissimo, C.; Bombardier, E.; Quadrilatero, J.; Tupling, A.R. Effects of sarcolipin deletion on skeletal muscle adaptive responses to functional overload and unload. Am. J. Physiol.-Cell Physiol. 2017, 313, C154-C161. [CrossRef]

70. Guerrero-Hernandez, A.; Sanchez-Vazquez, V.H.; Martinez-Martinez, E.; Sandoval-Vazquez, L.; Perez-Rosas, N.C.; LopezFarias, R.; Dagnino-Acosta, A. Sarco-Endoplasmic Reticulum Calcium Release Model Based on Changes in the Luminal Calcium Content. Adv. Exp. Med. Biol. 2020, 1131, 337-370. [CrossRef]

71. Batiste, S.M.; Blackwell, D.J.; Kim, K.; Kryshtal, D.O.; Gomez-Hurtado, N.; Rebbeck, R.T.; Cornea, R.L.; Johnston, J.N.; Knollmann, B.C. Unnatural verticilide enantiomer inhibits type 2 ryanodine receptor-mediated calcium leak and is antiarrhythmic. Proc. Natl. Acad. Sci. USA 2019, 116, 4810-4815. [CrossRef]

72. Nikolaienko, R.; Bovo, E.; Rebbeck, R.T.; Kahn, D.; Thomas, D.D.; Cornea, R.L.; Zima, A.V. The functional significance of redox-mediated intersubunit cross-linking in regulation of human type 2 ryanodine receptor. Redox Biol. 2020, $37,101729$. [CrossRef]

73. Lentz, L.R.; Valberg, S.J.; Balog, E.M.; Mickelson, J.R.; Gallant, E.M. Abnormal regulation of muscle contraction in horses with recurrent exertional rhabdomyolysis. Am. J. Vet. Res. 1999, 60, 992-999.

74. Lentz, L.R.; Valberg, S.J.; Herold, L.V.; Onan, G.W.; Mickelson, J.R.; Gallant, E.M. Myoplasmic calcium regulation in myotubes from horses with recurrent exertional rhabdomyolysis. Am. J. Vet. Res. 2002, 63, 1724-1731. [CrossRef]

75. Cole, F.L.; Mellor, D.J.; Hodgson, D.R.; Reid, S.W. Prevalence and demographic characteristics of exertional rhabdomyolysis in horses in Australia. Vet. Rec. 2004, 155, 625-630. [CrossRef]

76. Lopez, J.R.; Linares, N.; Cordovez, G.; Terzic, A. Elevated myoplasmic calcium in exercise-induced equine rhabdomyolysis. Pflüg. Arch. 1995, 430, 293-295. [CrossRef]

77. Voit, A.; Patel, V.; Pachon, R.; Shah, V.; Bakhutma, M.; Kohlbrenner, E.; McArdle, J.J.; Dell'Italia, L.J.; Mendell, J.R.; Xie, L.H.; et al. Reducing sarcolipin expression mitigates Duchenne muscular dystrophy and associated cardiomyopathy in mice. Nat. Commun. 2017, 8, 1068. [CrossRef]

78. Niranjan, N.; Mareedu, S.; Tian, Y.; Kodippili, K.; Fefelova, N.; Voit, A.; Xie, L.H.; Duan, D.; Babu, G.J. Sarcolipin overexpression impairs myogenic differentiation in Duchenne muscular dystrophy. Am. J. Physiol.-Cell Physiol. 2019, 317, C813-C824. [CrossRef]

79. Fajardo, V.A.; Chambers, P.J.; Juracic, E.S.; Rietze, B.A.; Gamu, D.; Bellissimo, C.; Kwon, F.; Quadrilatero, J.; Russell Tupling, A. Sarcolipin deletion in mdx mice impairs calcineurin signalling and worsens dystrophic pathology. Hum. Mol. Genet. 2018, 27, 4094-4102. [CrossRef]

80. Valberg, S.J. Muscle Anatomy: Adaptations to Exercise and Training. In The Athletic Horse: Principles and Practice of Equine Sports Medicine, 2nd ed.; Hodgson, D.R., McKeever, K.H., McGowan, C.M., Eds.; Saunders: New York, NY, USA, $2014 ;$ pp. $174-201$.

81. Valberg, S.J.; Perumbakkam, S.; McKenzie, E.C.; Finno, C.J. Proteome and transcriptome profiling of equine myofibrillar myopathy identifies diminished peroxiredoxin 6 and altered cysteine metabolic pathways. Physiol. Genom. 2018, 50, 1036-1050. [CrossRef] 